\title{
High sugar ryegrasses for livestock systems in New Zealand
}

\author{
G.R. EDWARDS ${ }^{1}$, A.J PARSONS ${ }^{2}$, S. RASMUSSEN ${ }^{2}$ and R.H. BRYANT ${ }^{1}$ \\ ${ }^{1}$ Agriculture Group, Agriculture and Life Sciences Division, Lincoln University, Canterbury, New Zealand, 7647 \\ ${ }^{2}$ AgResearch Grasslands, Private Bag 11008, Palmerston North, New Zealand
}

edwardsg@lincoln.ac.nz

\begin{abstract}
There has been mounting interest over the proposed production and environmental benefits from using perennial ryegrass cultivars bred to have higher water soluble carbohydrate content (high sugar grasses). Here, we objectively review published evidence, from the EU and New Zealand, of the effects of these on milk yield per cow, liveweight gain in sheep, $\mathrm{N}$ utilisation and wider trophic interactions. The literature reveals substantial variation in animal responses, though some of the uncertainty in interpretation can be resolved by combining the data from multiple trials, and showing this forms a continuum of response to diet quality. It also reveals variation in the degree to which the sugar trait has been expressed, possibly reflecting a gene $\mathrm{x}$ environment interaction. Achieving a more consistent, and probably greater than current, expression of the high sugar trait would be a valuable goal. We suggest 'proof of concept' has been shown, notably for the potential for improving $\mathrm{N}$ utilisation in the rumen, and so reducing the proportion of $\mathrm{N}$ intake lost in urine. The evidence suggests that this may be a greater challenge, albeit a more valuable goal, because of the relatively high $\mathrm{N}$ (crude protein) content forages that predominate in the New Zealand pasture industry.
\end{abstract}

Keywords: animal performance, high sugar grass, Lolium perenne, perennial ryegrass, nitrogen utilisation, trait expression, water soluble carbohydrates

\section{Introduction}

Plant breeders have developed perennial ryegrass cultivars with an elevated concentration of water soluble carbohydrates (WSC, also known as high sugar grasses) relative to conventional cultivars (Humphreys 1989a, b, c; Turner et al. 2006). This breeding has focussed on increasing the accumulation of high molecular weight storage sugars (i.e. fructans), particularly in leaf blades rather than sheath bases (Pollock \& Cairns 1991; Pavis et al. 2001a, b). It is proposed that perennial ryegrass with high WSC may improve the balance and synchrony of the nitrogen $(\mathrm{N})$ and carbon $(\mathrm{C})$ supply to the rumen (Miller et al. 2001a). This may lead to increased production in ruminants by improving the utilisation of $\mathrm{N}$ in the rumen and enhancing the supply of microbial protein to the ruminant (Miller et al. 2001a). This also potentially reduces the proportion of $\mathrm{N}$ in the diet that is lost in urine, thereby offering environmental benefits through reduced $\mathrm{N}$ leaching and emissions of the greenhouse gas nitrous oxide $\left(\mathrm{N}_{2} \mathrm{O}\right)$ (Di \& Cameron 2002). However, considerable debate has arisen over the benefits of high WSC grasses for New Zealand farming systems, including: the degree of improvement in livestock production and $\mathrm{N}$ utilisation; concerns over the expression of the high WSC trait under New Zealand conditions; and potential impacts on grazing preference, pasture composition and endophyte. This paper reviews the body of published evidence on the impact of high WSC grasses on these variables. The paper complements a more detailed review (Edwards et al. 2007) on the role of high WSC ryegrasses in New Zealand and Australian dairy industries.

\section{Expression of the high WSC trait}

Before any benefits of using high WSC ryegrasses can be anticipated across the industry, it is critical to consider just how consistently, and to what degree, an increase in WSC levels has been seen in practice. In UK and European pasture trials there has been a relatively consistent expression of the WSC trait in high WSC cultivars over control cultivars in the order of 10 to $50 \mathrm{~g}$ WSC/kg DM (Table 1, and see Cook et al. 2000; Orr et al. 2000; Halling et al. 2004) .

In New Zealand, in the first full year of field-based assessment of WSC concentration under grazing (Aorangi, Manawatu) (Parsons et al. 2004), only small and inconsistent differences in WSC content were recorded between the UK high WSC cultivar Aberdart and the UK control cultivar Fennema. Of note, is that these authors made clear their study did not include a New Zealand control cultivar, so conclusions couldn't be drawn about the expression of the high WSC trait in UK cultivars relative to New Zealand cultivars. Further examination of trait expression in controlled environments by Parsons et al. (2004), showed low temperatures per se increased sugars, notably high molecular weight sugars (fructans), in all cultivars, but a significant difference between the high WSC cultivars (AberDove and AberDart) and Fennema was apparent only after a sustained period of cold and short days (conditions comparable to leaving a UK winter). The major difference between the $24-40 \%$ elevation of sugars (between AberDart and Fennema) seen in the UK trials (Cook et 


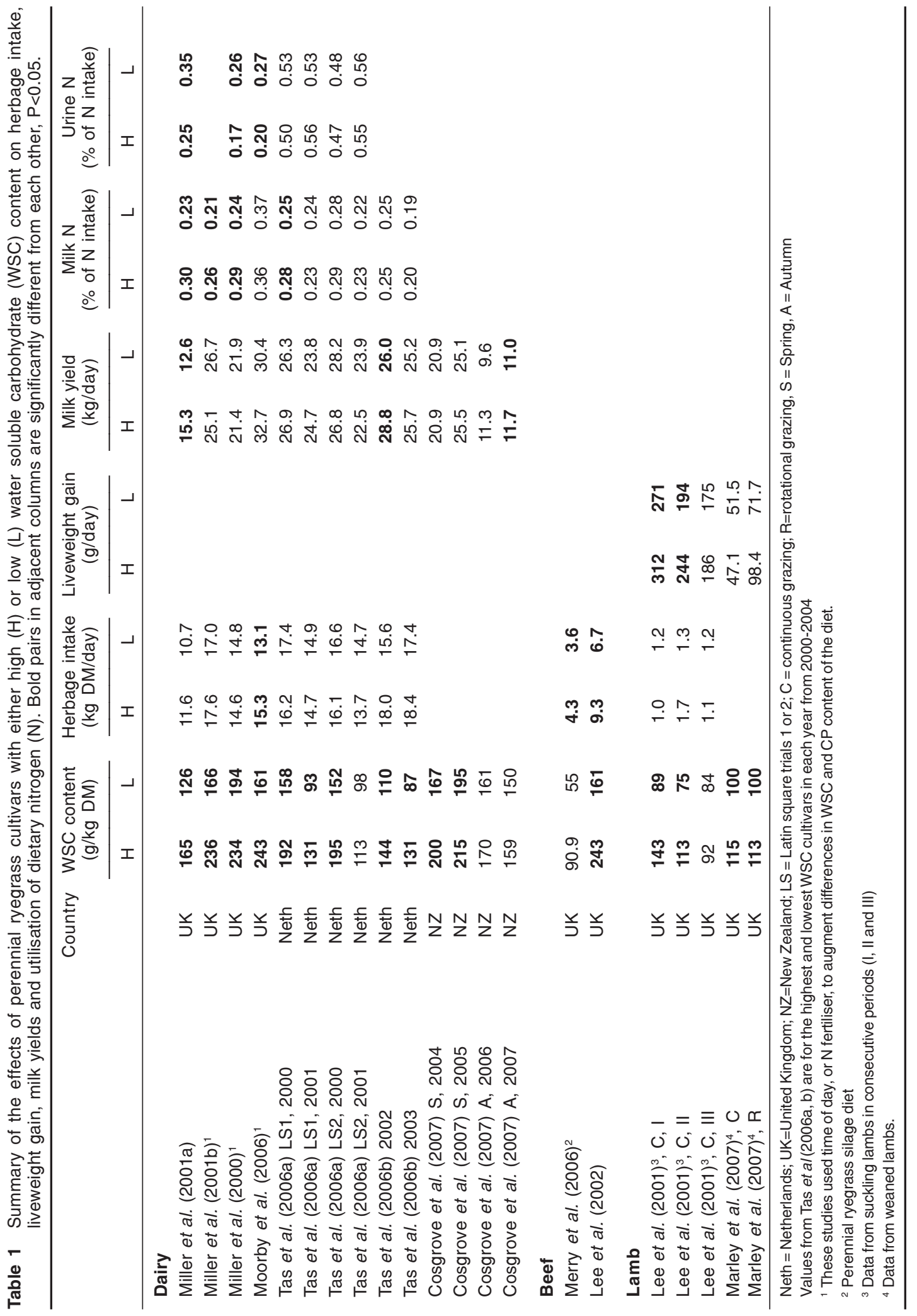


al. 2000; Orr et al. 2000) and in NZ at that time, led Parsons et al. (2004) to agree with Halling et al. (2004) on the possibility of a 'gene x environment interaction', in the trait expression, and on the prospects for developing more locally adapted cultivars. Programmes to develop such cultivars are underway both in NZ (using NZ germplasm) and across Europe.

More recent studies in the Manawatu show the UK high WSC cultivar AberDart had similar WSC to the NZ 'Italian' ryegrass Moata in two successive spring seasons, and both were 20 to $40 \mathrm{~g} \mathrm{WSC} / \mathrm{kg} \mathrm{DM}$ greater in WSC than the New Zealand control cultivar Impact (Tavendale et al. 2006; Cosgrove et al. 2007, Table 1). In two successive autumn seasons, in the same studies, there were much smaller differences $(0-9 \mathrm{~g} \mathrm{WSC} / \mathrm{kg}$ $\mathrm{DM}, \mathrm{P}>0.05$ ) in sugars between the cultivars (Table 1). Some other unpublished trials also show variable, seasonal and geographical, expression of the high WSC trait in New Zealand relative to New Zealand standard cultivars (D.E. Hume, unpublished data).

\section{Effects on dry matter (DM) production}

Harvestable DM production is seen as the primary driver of livestock production per ha in New Zealand farming systems. Thus, it is important to confirm that the elevation of WSC concentration does not occur at the expense of DM yield. The pan-European project ('Sweetgrass') in nine northern European (arguably cold) countries showed AberDart had consistently higher (c. $25 \mathrm{~g} / \mathrm{kg}$ ) sugar content than Fennema (Halling et al. 2004). However, in these studies total DM yield of Aberdart was significantly depressed, being significantly greater in only one site (in Wales) out of nine. Recent studies in New Zealand, using a range of UK derived high WSC cultivars in a multi site comparison, show these did not consistently differ in yield from NZ controls (Impact and Bronsyn) (D.E. Hume, unpublished data). Therefore, the current crown rust resistant, high sugar cultivars have DM yields at least as great, and on occasions greater, than New Zealand standard diploid cultivars, and are now also available with endophyte. For the industry this would seem therefore a 'one-sided bet'. That is, despite uncertainty over gains, there is no evidence of a detriment to DM production using the high WSC cultivars.

\section{Effect on livestock production}

Currently there is limited experimental evidence to indicate that high WSC perennial ryegrass cultivars will increase dairy cow production (Table 1). In one indoor study in the UK (Miller et al. 2001a), milk production of late lactation dairy cows was $2.7 \mathrm{~kg}$ /day greater $(\mathrm{P}<0.05)$ on a high than low WSC cultivar when cows were offered herbage that had been collected after a 6 week regrowth period in mid summer. However, Miller et al. (2001a) concluded that the difference was due to higher digestibility in the high WSC cultivar leading to greater intake of digestible DM. Moreover, in two further dairy studies, no differences were detected in milk yields in mid- (Miller et al. 2000) and early- (Moorby et al. 2006) lactation between a high WSC and control cultivar. This was despite the studies using either 'time of day' (diurnal patterns of sugar accumulation) or the application of $\mathrm{N}$ to the control areas, to accentuate differences between diet quality, as a means to test 'proof of concept'. Furthermore, in a further comprehensive set of indoor and outdoor studies in the Netherlands, intake and milk yield were unaffected by perennial ryegrass cultivars regardless of significant differences in WSC concentration (Tas et al. 2005, 2006a, b; Table 1).

In the only New Zealand (Manawatu) based study published to date (see Tavendale et al. 2006; Cosgrove et al. 2007), the yield of milk and milk solids of Friesian dairy cows grazing at pasture in two successive spring seasons did not differ among the high WSC cultivar Aberdart, the New Zealand perennial ryegrass control, Impact, and the NZ 'Italian' ryegrass Moata. In the first autumn also, milk yield and milk solids did not differ significantly $(\mathrm{P}>0.05)$ among cultivars. In the second autumn, milk yield $(\mathrm{P}=0.05)$, and milk solids $(\mathrm{P}=0.006)$ were significantly greater from the high WSC cultivar (Table 1) even though the difference in WSC concentration was only 0-9 g WSC $/ \mathrm{kg}$ DM. Cosgrove et al. (2007) concluded that while the milk production response in autumn could not be directly attributed to higher WSC, it may be related to other differences between grass types, such as a lower structural fibre of the high WSC grasses compared with the standard.

Working in the UK, and using some of the first germplasm lines produced with the high WSC trait, Lee et al. (2001) reported liveweight gain of continuously stocked suckling lambs was greater for a high WSC cultivar in two out of three periods. Earlier work in the UK showed that, over 2 years, total lamb production per ha from grass-only swards of Aurora (noted to be a high WSC cultivar, Humphreys 1989a; Smith et al. 2002) was $19 \%$ more than from the control cultivar Frances, despite similar herbage productivity (Munro et al. 1992). In contrast, Marley et al. (2007) did not detect any significant effect $(\mathrm{P}>0.05)$ of a high WSC cultivar on liveweight gain of weaned lambs grazing over 10 weeks in summer under either continuous or rotational grazing (Table 1).

In conclusion, there is an inconsistent response of intake, milk yield or liveweight gain to feeding high WSC cultivars (see also Hoeskstra et al. 2007). Clearly, there is a need for further science-focussed work to understand why results have been variable (seasonally and geographically) and also to explore how responses might 
Figure 1 Combined data from a range of both UK (IGER) and Dutch studies showing a continuum between $\mathrm{N}$ utilisation efficiency for milk (a) and urine (b) in dairy cows, in relation to the WSC:CP ratio of the forage component of the diet offered. Data sources: 2001 data from Tas et al. (2005, 2006a); $\square$ 2000 data from Tas et al. (2005, 2006a); $\Delta$ Miller et al. (2000); O Miller et al. (2001a); - Miller et al. (2001b); $\diamond$ Moorby et al. (2006); $\diamond$ Pacheco et al. (2007). Note, in all cases except Pacheco et al. (2007), the animals also received c. $4 \mathrm{~kg} /$ day concentrate.
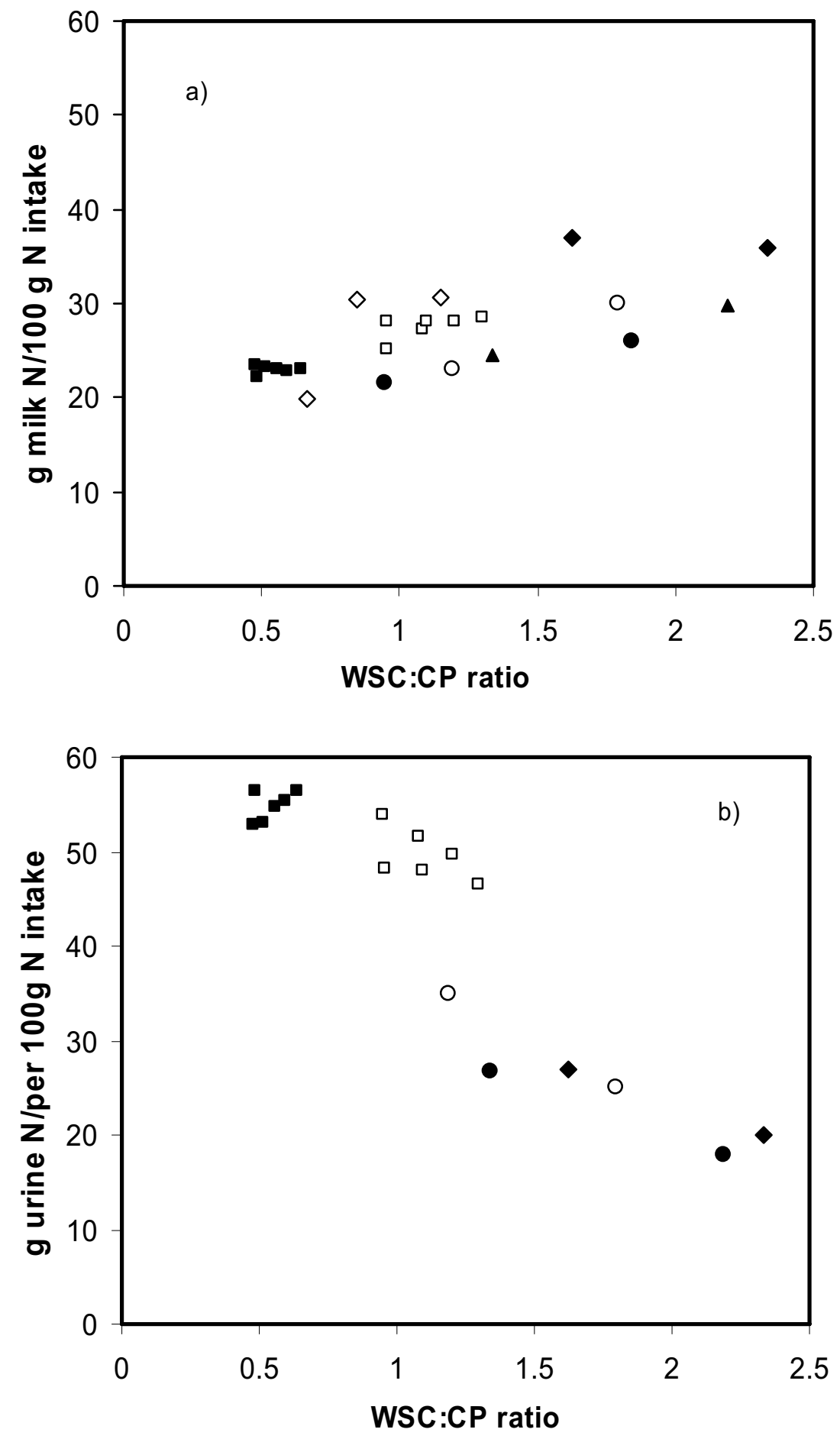
reflect the changing protein demands of the various livestock classes (Edwards et al. 2007). The increased supply of energy to the rumen is proposed to increase protein supply to the ruminant, and greater response might be expected in protein limited/demanding systems, than in energy limited ones. Furthermore, testing under grazing (as opposed to the predominantly indoor work in EU), and at the farm scale is needed to gain more evidence of how well the benefits are expressed under NZ farming conditions.

\section{Effect on $\mathbf{N}$ utilisation}

Initial dairy cow studies in the UK provided strong evidence that feeding dairy cows high WSC cultivars may improve $\mathrm{N}$ utilisation in the rumen as indicated by more efficient use of dietary $\mathrm{N}$ for milk production and less $\mathrm{N}$ excretion in urine (Table 1). Miller et al. (2001a) reported a significant reduction in urinary $\mathrm{N}$ and an increase in milk $\mathrm{N}$ (as a proportion of $\mathrm{N}$ eaten) in late lactation dairy cows consuming the high WSC cultivars. A significantly lower proportion of dietary $\mathrm{N}$ in urine for the high WSC than control cultivars was also noted in early (Moorby et al. 2006) and mid (Miller et al. 2000) lactation dairy cows housed indoors. Again the results of Moorby et al. (2006) and Miller et al. (2000) must be treated with some caution as methods were used to accentuate differences in WSC between cultivars. Moorby et al. (2006) cut the low WSC cultivar at 10:00 $\mathrm{h}$ and the high WSC cultivar at 14:00 $\mathrm{h}$ to emphasise the high WSC cultivar. Miller et al. (2000) applied an extra $50 \mathrm{~kg} \mathrm{~N} / \mathrm{ha}$ to the control grass in order to increase CP levels relative to WSC. Here, it is uncertain if the high WSC diet per se gave the benefits in reduced $\mathrm{N}$ emission in urine, or whether application of $\mathrm{N}$ to just the control treatment raised $\mathrm{N}$ in the control diet and confounded the effects of raised sugar in the high WSC diet.

Further support for the prospects of using higher WSC grasses to improve $\mathrm{N}$ efficiency also comes from studies with steers (Table 1). Lee et al. (2003) demonstrated, using in vitro rumen fermentation, the potential for greater $\mathrm{N}$ use efficiency, but were unable to demonstrate this in stall-fed steers (Lee et al. 2002). Merry et al. (2003, 2006) demonstrated (both in vitro and in vivo) that silage made from high WSC grasses did improve the incorporation of silage $\mathrm{N}$ into microbial $\mathrm{N}$, and saw notable benefits when grass silage was mixed with legume (red clover) silage (see Dewhurst et al. 2003a, b). In contrast, a further set of dairy cow studies in the Netherlands consistently reported little benefit of high WSC in improving $\mathrm{N}$ use efficiency (Tas et al. 2005, 2006a, b; Taweel et al. 2006), and attributed observed changes almost entirely to differences in total $\mathrm{N}$ intake (Tas 2007). The Dutch studies also drew attention to how the UK work had been conducted using forage diets of rather low crude protein $(\mathrm{CP})$ content.

In conclusion, the literature provides 'proof of concept' and promising support that $\mathrm{N}$ utilisation can be improved with the use of high WSC grasses, though the evidence suggests this may depend as much on the $\mathrm{N}$ environment in which the forage is grown, and so its $\mathrm{CP}$ content. Some of the variation (notably between the UK and Dutch studies) may be resolved by combining the data from the multiple trials and showing this forms a continuum of response to diet quality (Fig. 1a, b). The hypothesis for the benefits of high WSC grasses is that high WSC concentrations may correct an imbalance or asynchrony in the supply of energy and protein in the rumen. To test this directly, we need to compare $\mathrm{N}$ utilisation, not for a range of WSC contents, or N intakes, but for a range of WSC:CP ratios. Plotting the published data from both UK and the major Dutch trials, in relation to the WSC:CP ratio of the diet, suggests a common relationship between $\mathrm{N}$ use efficiency and WSC:CP ratio in dairy cows (see Figs. 1a, b). The lack of response in some trials can be seen to be because there were only small differences in WSC:CP ratio, despite large differences in WSC content.

From an environmental perspective, it is critical to confirm whether the $\mathrm{N}$ utilisation benefits will be evident under NZ conditions. These differ from circumstances in the EU in a number of ways: (i) a far greater proportion of the diet in New Zealand is forage based, so that modifications to forage quality will have greater impact, but (ii) diets of fresh forage have higher $\mathrm{N}$ content (and more legume) in New Zealand than in the EU (more so as NZ intensifies dairy agriculture). For example, in the studies of Miller et al. (2000, 2001a) and Moorby et al. (2006), the ryegrass had a CP content ranging from just 92-145 g CP/kg DM. These are low in comparison to the concentrations reported in studies of grazed pasture in New Zealand (e.g. mean $185 \mathrm{~g} \mathrm{CP} / \mathrm{kg} \mathrm{DM}$; range 50$362 \mathrm{~g} \mathrm{CP} / \mathrm{kg} \mathrm{DM}$ ) (Corson et al. 1999). Although CP concentrations in pasture may be inadequate for maximum pasture growth, they generally exceed requirements for milk production (NRC 2001). Under these conditions, where livestock requirements for protein are satisfied, the environmental benefits of high WSC to improve $\mathrm{N}$ utilisation and reduce $\mathrm{N}$ excretion in urine are more likely to be seen. However this will depend on whether WSC can be elevated sufficiently to restore WSC:CP ratio above c. 0.7 (Fig. 1). This we calculate (Edwards et al. 2007) may require increases in WSC of 100-200+ g WSC/kg DM, values far greater than has consistently been achieved to date.

\section{Wider Implications of High WSC Grasses WSC cultivar $x$ environment $x$ management interactions}

Changes in WSC concentration, in the form and priorities 
for metabolic pathways during regrowth, and in response to temperature are well documented (Morvan-Bertrand et al. 2001; Lasseur et al. 2007). Sugars increase substantially during regrowth following defoliation, and regrowth is generally faster at warm temperatures (defined in the context of each species' adaptive range).

Likewise, low temperatures per se lead to a substantially greater total WSC. These responses expose a possible conflict. On the one hand, warm temperatures may stimulate increases in WSC by stimulating recovery of leaf area during regrowth. On the other hand, warm temperatures may reduce sugars relative to colder temperatures. Thus, there is a potential environment (temperature) $\mathrm{x}$ management (regrowth duration) interaction. Studies of WSC concentration during contrasting regrowth intervals at different temperatures might only confirm long standing knowledge of the optimal defoliation regime for given local climates. But, if at the same time measures were made of just which genes/pathways were expressed and contributed to sugar level control, then greater opportunities for removing the source of some of the uncertainty in expression in the high WSC trait, may be realised.

\section{WSC cultivar $x$ grazing management interactions}

Water soluble carbohydrates are major metabolic and storage components in perennial ryegrass. Thus, if perennial ryegrass is allowed to grow to greater pasture mass, it may be expected to contain higher WSC. Further, grazing systems that allow greater accumulation of pasture mass (e.g. rotational grazing) might be expected to have higher WSC concentrations than those that are maintained at low pasture mass (e.g. continuous grazing). In the UK, Marley et al. (2007) tested this idea, but found no difference in the differential of WSC concentration between the high WSC cultivar Aberdart and the control cultivar Fennema between rotational and continuous sheep grazing. But note also in the Marley et al. (2007) study that there was little difference in WSC content between cultivars.

\section{WSC cultivar $x$ nutrient cycling interactions}

A decrease in urine $\mathrm{N}$, and a greater relative release of organic $\mathrm{N}$ in dung, may have immediate environmental benefits in reducing $\mathrm{N}$ leaching and emissions of greenhouse gases (Di \& Cameron 2002). However, it is unclear how possible changes in root exudation of sugars or sustained changes in the $\mathrm{C}: \mathrm{N}$ ratio of decaying plant biomass, would affect the function of major microbial systems in the soil. Of note is that changes in leaf WSC concentration potentially parallel, and may even exceed, the proposed impacts of elevated atmospheric $\mathrm{CO}_{2}$ seen as a part of climate change (Edwards \& Newton 2007; Newton \& Edwards 2007). Research is underway to evaluate if major changes in plant quality could mitigate, or exacerbate, impacts due to 'climate change'.

\section{WSC cultivar $x$ endophyte interactions}

In New Zealand, the endophyte (Neotyphodium lolii) status of perennial ryegrass is of crucial importance in determining the grasses agronomic value and impact on livestock (Easton \& Fletcher 2007). Any changes in endophyte concentration and in the secondary metabolites they produce may thus have important implications for New Zealand pasture systems. Rasmussen et al. (2007) studied interactions between high WSC cultivars, fungal endophyte strains and $\mathrm{N}$ supply in a laboratory study. They showed that the endophyte concentration determined by quantitative PCR - was reduced by $40 \%$ under high N supply and by $50 \%$ in the high WSC cultivar (Fig. 2). Production of the alkaloids peramine, ergovaline, janthitrems and lolitrem $B$ were also reduced under both high N supply and in the high WSC cultivar, and in both cases the effects of $\mathrm{N}$ supply and high WSC were additive.

In conclusion, the changes in response to WSC content and $\mathrm{N}$ supply may have important implications for $\mathrm{New}$ Zealand pasture systems by affecting the balance of risk (e.g. toxicity) and benefit (e.g. insect deterrence) of having endophyte in the pasture. What remains a concern is whether the concentration of peramine - the alkaloid responsible for deterrence of Argentine stem weevil - is at times reduced below critical levels for protection from this insect, thus jeopardising plant productivity. However, this concern is based on one laboratory study and field based studies of interactions between endophyte, high WSC cultivars, $\mathrm{N}$ fertiliser and insect pest attack are currently underway to determine the generality of this response.

\section{WSC cultivar $\mathbf{x}$ diet preference $\mathbf{x}$ pasture composition interactions}

If the high WSC trait were to alter grazing preference there may be important implications for the persistence of pastures, pasture quality and pasture composition (Cosgrove \& Edwards 2007). Mayland et al. (2000) noted cattle preference for tall fescue cultivars was positively correlated with total non structural carbohydrate, while Smit (2005) found dairy cows consistently preferred perennial ryegrass cultivars with a high WSC concentration.

The potential impacts of this preference may be positive or negative. On the one hand, high preference may promote overgrazing and reduced persistence. On the other hand, high preference may overcome the reluctance of dairy cows to graze to the low pasture residuals (e.g. 1300 to $1500 \mathrm{~kg} \mathrm{DM} / \mathrm{ha}$ ) that are proposed in New Zealand (Hoogendoorn et al. 1988; van Bysterveldt 
Figure 2 Main effects of (a) cultivar and (b) N availability on fungal endophyte concentrations expressed as the number of copies of two 'single copy' fungal genes NRPS-1 and chitinase per unit total (plant plus fungal) genomic DNA. Black bars denote NRPS-1, white bars denote chitinase. Aberdove = high WSC cultivar; Fennema = control WSC cultivar. Bars show the untransformed means and standard errors. There were no significant interactions. (From Rasmussen et al. 2006, with permission from New Phytologist).

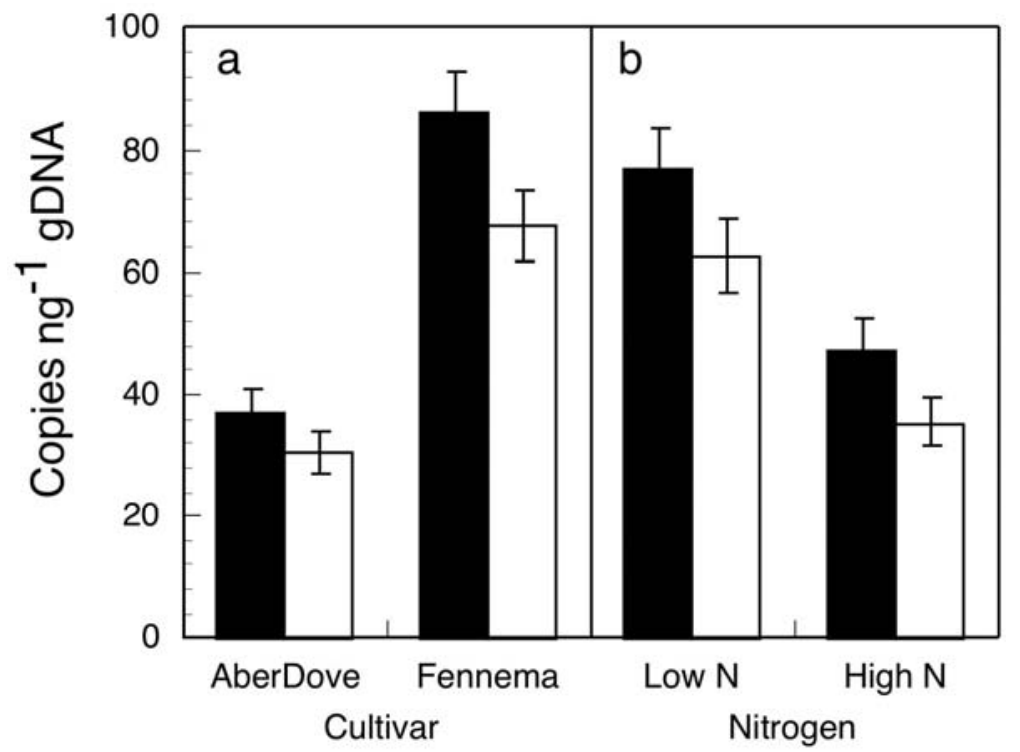

\section{Main Effects of Treatment}

2005 ) to enhance pasture quality (e.g. by better white clover growth and by reducing seed head development and build up of dead material). Further, the proportion of white clover in the pasture may also be increased if the use of high WSC cultivars reduces the partial preference (60-70\%) observed for white clover (Parsons et al. 1994; Cosgrove \& Edwards 2007). The one study set up to test this (Francis et al. 2006) was hampered by the lack of significant difference in WSC between high and control cultivars, and no difference in partial preference for white clover was observed.

Consequently, the use of high WSC grasses may potentially have important impacts on pasture composition. However, there are limited data available to confirm this. To date, studies of high WSC perennial ryegrasses have generally used pure perennial ryegrass swards so that measurements of pasture chemical composition and animal response are not confounded by the presence of clover. Ultimately, the value of grasses whether high WSC or conventional cultivars - should be assessed in the presence of clover as they are used onfarm (Harris 1990). There is considerable scope in which to investigate this. For example, Munro et al. (1992) showed that the increase in lamb output between Aurora (high WSC cultivar, Humphreys 1989a; Smith et al. 2002) and control ryegrasses was more pronounced when the ryegrass was grown with clover than as a pure sward.

\section{Future prospects for meeting WSC:CP goals}

Progress to date in increasing the sugar concentration of perennial ryegrass by traditional breeding has seen annual gains of "approximately $4 \mathrm{~g} \mathrm{WSC} / \mathrm{kg}$ DM" from 19922000 , accompanied by a $1 \mathrm{~g} \mathrm{WSC} / \mathrm{kg}$ DM per annum reduction in CP (Wilkins \& Lovatt 2003; and see Marais et al. 2003). In keeping with this, our review points towards differences in the field between high WSC cultivars and controls which are rarely greater than $40 \mathrm{~g}$ WSC/kg DM. Earlier, we argued that a greater and more consistent expression of the trait in plants may be necessary. Molecular techniques may offer the greatest prospects for going beyond the existing, potentially conservative, natural range of expression. Detailed studies of gene expression and associated enzyme activity could provide benefits from better understanding per se, but molecular techniques also offer prospects for non transgenic (cisgenic) if not fully transgenic, up-regulation of the trait (see Edwards et al. 2007 for discussion of molecular biology approaches to improving WSC trait expression).

\section{Conclusion}

- The development of perennial ryegrass cultivars with high WSC represents a substantial effort to progress industry goals of greater production with an eye to environmental concerns. This work displays an 
exemplary level of commitment, not just to developing forage plants, but to testing 'proof of concept' and to ensuring the proposed benefits can be exhibited through animals. The proposed benefits of the trait have been exposed to a level of scrutiny that has, to be fair, been far greater, and more critical, possibly than for any other grass cultivar development (see e.g. Crush et al. 2006).

- Available evidence reveals substantial variation in livestock production responses but the effect has never been negative. A more consistent response of improved $\mathrm{N}$ utilisation was noted across studies, indicating valuable potential prospects for reducing environmental impacts of farming if the WSC:CP ratio can be elevated in the high CP forages grown in New Zealand.

- There is a serious need for further field based, year round, confirmation, of how well the trait is expressed and how great the animal responses are under New Zealand conditions. Here, research should move beyond the current short term studies to include farm scale evaluations so the full ramifications of the trait under different farm managements can be explored. But it is important these studies have an appropriate control treatment, an adjacent area resown with a control cultivar to ensure the benefits of resowing with a high WSC grass are due to the grass cultivar per se and not the benefits of resowing per se (eg N mineralisation).

- But field/farm based studies alone may not suffice. These can serve to establish whether current forage germplasm works at present, but run the risk that further evidence of uncertain performance benefits will dismiss future prospects completely. Science-focussed research is also needed (it was, after all, the origin of the opportunity) to explain the variation seen to date; to elevate WSC sufficiently to restore WSC:CP ratio in high $\mathrm{N}$ forage, and so to secure future opportunities.

- Areas in which additional research is required are the molecular basis of the control of sugar accumulation, effects of high WSC cultivars on pasture composition and pasture persistence (pests/weeds), and interactions with endophyte and mycorrhizae, under a range of NZ grazing management combinations.

\section{ACKNOWLEDGEMENTS}

This review was partly funded by Pastoral 21: Delivering sustainable forage productivity gains, C10X0604.

\section{REFERENCES}

Corson, D.C.; Waghorn, G.C.; Ulyatt, M.J.; Lee, J. 1999. NIRS: forage analysis and livestock feeding. Proceedings of the New Zealand Grassland Association 61: 127-132.

Cook, J.E.; Champion, R.A.; Orr, R.J.; Rook, A.J. 2000. Intake rate, grazing time and daily intake by sheep grazing perennial ryegrass varieties under continuous stocking management. pp 67-68. In: Proceedings of the 6th British Grassland Society Research Conference, Aberdeen, 11-13 Sept 2000.

Cosgrove, G.P.; Edwards, G.R. 2007: Control of grazing intake. pp 61-80. In: Pastures and supplements for grazing animals. Eds. Rattray P.V.; Brookes, I.M.; Nicol, A.M. New Zealand Society of Animal Production. Occasional publication No. 14.

Cosgrove, G.P.; Pacheco, D.; Burke, J.L.; Lane, G.A. 2007. Improved water-soluble carbohydrate in forages: evaluating the potential for grazing dairy cows in NZ. Proceedings of the New Zealand Grassland Association 69: 179-185.

Crush, J.R.; Woodward, S.L.; Eerens, J.P.J.; MacDonald, K.A. 2006. Growth and milk solids production in pastures of older and more recent ryegrass and white clover cultivars under dairy grazing. New Zealand Journal of Agricultural Research 49: 119-135.

Dewhurst, R.J.; Fisher, W.J.; Tweed, J.K.S.; Wilkins, R.J. 2003a. Comparison of grass and legume silages for milk production 1. Production responses with different levels of concentrates. Journal of Dairy Science 86: 2612-2621.

Dewhurst, R.J.; Evans, R.T.; Scollan, N.D.; Moorby, J.M.; Merry, R.J.; Wilkins, R.J. 2003b. Comparison of grass and legume silages for milk production 2. In vivo and in sacco evaluations of rumen function. Journal of Dairy Science 86: 2598-2611.

Di, H.J.; Cameron, K.C. 2002. The use of a nitrification inhibitor, dicyandiamide (DCD), to decrease nitrate leaching and nitrous oxide emissions in a simulated grazed and irrigated grassland. Soil Use and Management 18: 395-403.

Easton, H.S.; Fletcher, L.R. 2007. The importance of endophyte in agricultural systems - changing plant and animal productivity. Proceedings of the 6th International Symposium on Fungal Endophytes of Grasses. Grassland Research and Practice Series No. 13: 11-18

Edwards, G.R.; Parsons, A.J; Rasmussen, S. 2007. High sugar ryegrasses for dairy systems. pp 307-334. In: Meeting the challenges for pasture-based dairying. Proceedings of the 3rd Dairy Science Symposium. Eds. Chapman, D.F.; Clark, D.A.; Macmillan, K.L.; Nation, D.P. 18-20 September 2007, University of Melbourne, Victoria, Australia. Published by the National Dairy Alliance.

Edwards, G.R.; Newton, P.C.D. 2007. Plant performance and implications for plant population dynamics and species composition in a changing climate. pp.189210. In: Agroecosystems in a changing climate. Eds. Newton, P.C.D.; Edwards, G.R.; Niklaus, P.; Carran, A.R.. Advances in Agroecology Series, CRC press, 
Boca Raton, USA.

Francis, S.A.; Chapman, D.F.; Doyle, P.T.; Leury, B.J. 2006. Dietary preferences of cows offered choices between white clover and 'high sugar' and 'typical' perennial ryegrass cultivars. Australian Journal of Experimental Agriculture 46: 1579-1587.

Halling, M.A.; Longland, A.C.; Martens, S.; Nesheim, L.; O'Kiely, P. 2004. Accumulation of water soluble carbohydrates in two perennial ryegrass cultivars at nine European sites. Grassland Science in Europe. Land use systems on grassland dominated regions. pp 954-956. In: European Grassland Federation (EGF) 20th General Meeting. Eds. Luscher A.; Jeangros, B.; Kessler, W.; Huguenin, O.; Lobsiger, M.; Millar, N.; Suter, D. Luzern, Switzerland, 21-24 June 2004.

Harris, W. 1990. Pastures as an ecosystem. pp 75-131 In: Pastures their Ecology and Management. Ed. Langer, R.H.M. Oxford University Press. Oxford.

Hoekstra, N.J.; Schulte, R.P.O.; Struik, P.C.; Lantinga, E.A. 2007. Pathways to improving the $\mathrm{N}$ efficiency of grazing bovines. European Journal of Agronomy 26: 363-374.

Hoogendoorn, C.J.; Holmes, C.W.; Chu, A.C.P: 1988. Grazing management in spring and subsequent dairy cow performance. Proceedings of the New Zealand Grassland Association 49: 7-10.

Humphreys, M.O. 1989a. Water-soluble carbohydrates in perennial ryegrass breeding. I. Genetic differences among cultivars and hybrid progeny grown as spaced plants. Grass and Forage Science 44: 231-236.

Humphreys, M.O. 1989b. Water-soluble carbohydrates in perennial ryegrass breeding. II. Cultivars and hybrid progeny performance in cut plots. Grass and Forage Science 44: 237-244.

Humphreys, M.O. 1989c. Water-soluble carbohydrates in perennial ryegrass breeding. III. Relationships with herbage production, digestibility and crude protein content. Grass and Forage Science 44: 423-429.

Lasseur, B.; Lothier, J.; Morvan-Bertrand, A.; EscobarGuttiérez, A.; Humphreys, M. O.; Prud'homme, M. 2007. Impact of defoliation frequency on regrowth and carbohydrate metabolism in contrasting varieties of Lolium perenne. Functional Plant Biology 34: 418430.

Lee, M.R.F.; Jones, E.L.; Moorby, J.M.; Humphreys, M.O.; Theodorou, M.K.; MacRae, J.C.; Scollan, N.D. 2001. Production responses from lambs grazed on Lolium perenne selected for an elevated water-soluble carbohydrate concentration. Animal Research 50: 441449.

Lee, M.R.F.; Harris, L.J.; Moorby, J.M.; Humphreys, M.O.; Theodorou, M.K.; MacRae, J.C.; Scollan, N.D. 2002. Rumen metabolism and nitrogen flow to the small intestine in steers offered Lolium perenne containing different levels of water-soluble carbohydrate. Animal Science 74: 587-596.

Lee, M.R.F.; Merry, R.J.; Davies, D.R.; Moorby, J.M.; Humphreys, M.O.; Theodorou, M.K.; MacRae, J.C.; Scollan, N.D. 2003. Effect of increasing availability of water-soluble carbohydrates on in vitro rumen fermentation. Animal Feed Science and Technology 104: 59-70.

Marais, J.P.; Goodenough, D.C.W.; de Figueiredo, M.; Hopkins, C. 2003. The development of a Lolium multiflorum cultivar with a low moisture content and an increased readily digestible energy to protein ratio. Australian Journal of Agricultural Research 54: 101106.

Marley, C.L.; Fraser, M.D.; Fisher, W.J.; Forbes, A.B.; Jones, R.; Moorby, J.M.; MacRae, J.C.; Theodorou, M.K. 2007. Effects of continuous or rotational grazing of two perennial ryegrass varieties on the chemical composition of the herbage and the performance of finishing lambs. Grass and Forage Science 62: 255264.

Mayland, H.F.; Shewmaker, G.E.; Harrison, P.A.; Chatterton, N.J. 2000. Nonstructural carbohydrates in tall fescue cultivars: Relationship to animal preference. Agronomy Journal 92: 1203-1206.

Merry, R.J.; Lee, M.R.F.; Davies, D.R.; Moorby, J.M.; Dewhurst, R.J.; Scollan, N.D. 2003. Nitrogen and energy use efficiency in the rumen of cattle fed high sugar grass and/or red clover silage. Aspects of Applied Biology 70: 87-92.

Merry, R.J.; Lee, M.R.F.; Davies, D.R.; Dewhurst, R.J.; Moorby, J.M.; Scollan, N.D.; Theodorou, M.K. 2006. Effects of high-sugar ryegrass silage and mixtures with red clover silage on ruminant digestion. 1. In vitro and in vivo studies of nitrogen utilisation. Journal of Animal Science 84: 3049-3060.

Miller, L.A.; Theodorou, M.K.; MacRae, J.C.; Evans, R.T.; Humphreys, M.O.; Scollan, N.D.; Moorby, J.M. 2000. Efficiency of nitrogen use by dairy cows offered perennial ryegrass with high water soluble carbohydrate concentrations. pp 37-38. In: Proceedings of the 6th Research Conference of the British Grassland Society, Aberdeen, 11-13 September 2000, British Grassland Society, Reading.

Miller, L.A.; Moorby, J.M.; Davies, D.R.; Humphreys, M.O.; Scollan, N.D.; MacRae, J.C.; Theodorou, M.K. 2001a. Increased concentration of water-soluble carbohydrate in perennial ryegrass (Lolium perenne L.): milk production from late-lactation dairy cows. Grass and Forage Science 56: 383-394.

Miller, L.A.; Baker, D.H.; Theodorou, M.K.; MacRae, J.C.; Humphreys, M.O.; Scollan, N.D.; Moorby, J.M. 2001b. Efficiency of nitrogen use in dairy cows grazing ryegrass with different water soluble carbohydrate 
concentrations. pp 377-378. In: Grassland Ecosystems: An outlook into the 21st Century. Eds. Gomide, J.A.; Mattos, W.R.S.; Carneiro da Silva, S. Proceedings of the 19th International Grasslands Congress, Sao Paulo, Brazil, 10-21 February, 2001. Moorby. J.M.; Evans, R.T.; Scollan, N.D.; MacRae, J.C.; Theodorou, M.K. 2006. Increased concentration of water-soluble carbohydrate in perennial ryegrass (Lolium perenne L.). Evaluation in dairy cows in early lactation. Grass and Forage Science 61: 52-59.

Morvan-Bertrand, A.; Boucaud, J.; Le Saos, J.; Prud'homme, M-P. 2001. Roles of fructans from leaf sheaths and from the elongating leaf bases in the regrowth following defoliation of Lolium perenne $\mathrm{L}$. Planta 213: 109-120.

Munro, J.M.M.; Davies, D.A.; Evans, W.B.; Scurlock, R.V. 1992. Animal production evaluation of herbage varieties. 1. Comparison of Aurora with Frances, Talbot and Melle perennial ryegrasses when grown alone or with clover. Grass and Forage Science 47: 259-273.

Newton, P.C.D.; Edwards, G.R. 2007. Plant breeding for a changing climate. pp. 309-319. In: Agroecosystems in a changing climate. Eds. Newton, P.C.D.; Edwards, G.R.; Niklaus, P.; Carran, A.R., Advances in Agroecology Series, CRC Press, Boca Raton, USA.

NRC. 2001. Nutrient requirements of dairy cattle. 7th revised edition. National Academy of Sciences, Washington, DC.

Orr, R.J.; Cook, J.E.; Atkinson, L.D.; Clements, R.O.; Martyn, T.M. 2000. Evaluation of herbage varieties under continuous stocking. pp 39-44. In: Grazing Management. Eds. Rook, A.J.; Penning, P.D. Occasional Symposium No 34 British Grassland Society, Reading, UK.

Pacheco, D.; Burke, J.L.; Cosgrove, G.P. 2007. An empirical model to estimate efficiency of nitrogen utilisation from cows grazing fresh forages. pp 417422. In: Meeting the challenges for pasture-based dairying. Proceedings of the 3rd Dairy Science Symposium. Eds. Chapman, D.F.; Clark, D.A.; Macmillan, K.L.; Nation, D.P. 18-20 September 2007, University of Melbourne, Victoria, Australia. Published by the National Dairy Alliance.

Parsons, A.J.; Newman, J.A.; Penning, P.D.; Harvey, A.; Orr, R.J. 1994. Diet preference of sheep: effects of recent diet, physiological state and species abundance. Journal of Animal Ecology 63: 465-478.

Parsons, A.J.; Rasmussen, S.; Xue, H.; Newman, J.A.; Anderson, C.B.; Cosgrove, G.P. 2004. Some high sugar grasses don't like it hot. Proceedings of the New Zealand Grassland Association 66: 265-272.

Pavis, N.; Boucaud, J; Prud'homme, M.P. 2001a. Fructans and fructan metabolizing enzymes in leaves of Lolium perenne. New Phytologist 150: 97-109.

Pavis, N.; Chatterton, N.J.; Harrison, P.A.; Baumgartner, S.; Praznik, W.; Boucaud, J.; Prud'homme, M.P. $2001 \mathrm{~b}$. Structure of fructans in roots and leaf tissues of Lolium perenne. New Phytologist 150: 83-95.

Pollock, C.J.; Cairns, A.J. 1991: Fructan metabolism in grasses and cereals. Annual Review of Plant Physiology and Plant Molecular Biology 42: 77-101.

Rasmussen S.; Parsons, A.J.; Bassett, S.; Christensen, M.J.; Hume, D.E.; Johnson L.J.; Johnson, R.D.; Simpson, W.R.; Stacke, C.; Voisey, C.R.; Xue, H.; Newman, J.A. 2006. High nitrogen supply and carbohydrate content reduce fungal endophyte and alkaloid concentration in Lolium perenne. New Phytologist 173: 787-797.

Smit, H.J. 2005. Perennial ryegrass for dairy cows: effects of cultivar on herbage intake during grazing. $\mathrm{PhD}$ Thesis, Wageningen University, Wageningen.

Smith, K.F.; Culvenor, R.A.; Humphreys, M.O; Simpson, R.J. 2002. Growth and carbon partitioning in perennial ryegrass (Lolium perenne) cultivars selected for high water-soluble carbohydrate concentrations. Journal of Agricultural Science 138: 375-385.

Tas, B.M.; Taweel, H.Z.; Smit, H.J.; Elgersma, A.; Dijkstra, J.; Tamminga, S. 2005. Effects of perennial ryegrass cultivars on intake, digestibility and milk yield in dairy cows. Journal of Dairy Science 88: 32403248.

Tas, B.M.; Taweel, H.Z.; Smit, H.J.; Elgersma, A.; Dijkstra, J.; Tamminga, S. 2006a. Utilisation of $\mathrm{N}$ in perennial ryegrass cultivars by stall-fed lactating dairy cows. Livestock Science 100: 159-168.

Tas, B.M.; Taweel, H.Z.; Smit, H.J.; Elgersma, A.; Dijkstra, J.; Tamminga, S. 2006b. Effects of perennial ryegrass cultivars on milk yield and nitrogen utilisation in grazing dairy cows. Journal of Dairy Science 89: 3494-3500.

Tas, B.M. 2007. Nitrogen utilisation of perennial ryegrass in dairy cows. pp 125-140. In: Fresh herbage for dairy cattle. Eds. Elgersma A.; Dijkstra, J.; Tamminga, S. Springer, The Netherlands.

Tavendale, M.H.; Pacheco, D.; Lane, G.A.; Fraser, K.; Death, A.F.; Burke, J.L.; Hickey, M.J.; Cosgrove, G.P. 2006. The effects of ryegrass varieties differing in soluble sugar content on the rumen fermentation of amino acids and consequences for milk flavour chemistry. Proceedings of the New Zealand Grassland Association 68: 267-273.

Taweel, H.Z.; Tas, B.M.; Smit, H.J.; Elgersma, A.; Dijkstra, J.; Tamminga, S. 2006. Grazing behaviour, intake, rumen function and milk production of dairy cows offered Lolium perenne containing different levels of water-soluble carbohydrates. Livestock 
Science 102: 33-41.

Turner, L.B.; Cairns, A.J.; Armstead P.; Ashton, J.; SkØt, K.; Whittaker, D.; Humphreys, M.O. 2006. Dissecting the regulation of fructan metabolism in perennial ryegrass (Lolium perenne) with quantitative trait locus mapping. New Phytologist 169: 45-58.

van Bysterveldt, A. 2005. Lincoln University dairy farm, now a cropping farm? pp 18-29 In: Proceedings of the South Island Dairy Event.

Wilkins, P.W.; Lovatt, J.A. 2003. Progress in improving the ratio of water-soluble carbohydrate to crude protein in perennial ryegrass. pp 31-36. In: Aspects of Applied Biology Vol. 70, Proceedings 'Crop Quality: Its role in sustainable livestock production', Association of Applied Biologists Conference, Manchester, 15-16 December. 